\title{
Response of Twenty Tall Fescue (Schedonorus arundinaceus (Schreb.) Dumort.) Cultivars to Low Mowing Height
}

\author{
Marco Schiavon $^{1}\left(\mathbb{D}\right.$, Stefano Macolino ${ }^{2}(\mathbb{D})$ and Cristina Pornaro $^{2, *(\mathbb{D})}$ \\ 1 Fort Lauderdale Research and Education Center, Environmental Horticulture Department, \\ University of Florida, Davie, FL 33314, USA; marcoschiavon@ufl.edu \\ 2 Department of Agronomy, Food, Natural Resources, Animals, and Environment, University of Padova, \\ 35020 Padova, Italy; stefano.macolino@unipd.it \\ * Correspondence: cristina.pornaro@unipd.it
}

check for updates

Citation: Schiavon, M.; Macolino, S.; Pornaro, C. Response of Twenty Tall Fescue (Schedonorus arundinaceus (Schreb.) Dumort.) Cultivars to Low Mowing Height. Agronomy 2021, 11, 943. https://doi.org/10.3390/ agronomy11050943

Academic Editor: Nikolaos Ntoulas

Received: 24 March 2021

Accepted: 6 May 2021

Published: 10 May 2021

Publisher's Note: MDPI stays neutral with regard to jurisdictional claims in published maps and institutional affiliations.

Copyright: (C) 2021 by the authors. Licensee MDPI, Basel, Switzerland. This article is an open access article distributed under the terms and conditions of the Creative Commons Attribution (CC BY) license (https:// creativecommons.org/licenses/by/ $4.0 /)$.

\begin{abstract}
Tall fescue (Schedonorus arundinaceus (Schreb.) Dumort.) is the most widely used species in the European transition zone, however, despite its good wear tolerance, its use is still limited to lawns and landscape areas due to concerns about its ability to withstand low mowing regimes. A two years field study was conducted to access performance of twenty tall fescue cultivars ('Ares', 'Armani', 'Dynamites LS', 'Firecracker SLS', 'Firewall', 'Foxhound' ‘Granditte', 'JT-LT2' , 'JT-338', 'Karakum', 'Lexington', 'Olympic Gold', 'Rebounder', 'Rhambler SRP', 'Starlett', 'Supersonic', 'Talladega', 'Thunderstruck', 'Titanium 2LS', 'Turfway') mowed weekly at $18 \mathrm{~mm}$. Turfgrass was evaluated every two weeks for visual quality, color, density, texture and uniformity, as well as percent green cover (PGC) and dark green color index (DGCI), and normalized difference vegetation index (NDVI), and traction twice per year. Although no cultivars showed sufficient quality throughout the year, 'Turfway', 'Titanium 2LS' and 'JT-338' achieved high quality rating during spring and fall, the two seasons with the highest frequency of games played on sports field in northern Italy. Traction ratings collected in these study fell within acceptable range for football fields. Our results suggest that improved dwarf-type tall fescue cultivars can be used in sport fields in Northern Italy.
\end{abstract}

Keywords: visual quality; color; density; texture; uniformity; percent green cover; dark green color index; NDVI

\section{Introduction}

The drought avoidance, and tolerance to several abiotic stressors such as warm temperatures, shade, salinity, and wear of tall fescue (Schedonorus arundinaceus (Schreb.) Dumort.) make it more desirable compared to other cool-season species in the transition zone [1-4]. Recently, Schiavon et al. [4] demonstrated that differences in new and improved tall fescue cultivars exist in transition zones with humid subtropical climate such as northeastern Italy. Moreover, this species has been predominately used as a landscape species and seldom for the constitution of sports fields, where Kentucky bluegrass (Poa pratensis L.), and perennial ryegrass (Lolium perenne L.) are often preferred [5,6]. Tall fescue is a bunch-type species without stolons, but can produce short rhizomes [7]. However, these short rhizomes do not facilitate rapid, lateral spread and recovery caused by damage or disease. The lower quality and slow recovery from disease in tall fescue is addressed by mixing it with Kentucky bluegrass [8-11], and such mixtures could be more suitable for sport fields. However, the main reasons for its lack of use in sports fields is insufficient tolerance to low mowing height [5].

Despite being a forage type, the first turfgrass-type tall fescue cultivar was Kentucky 31. Rebel was the first turf-type cultivar with finer leaf texture and darker green color to be released in 1979, and since then a great number of improved, turf-type varieties have been developed by the breeding industry, increasing the use of tall fescue in the landscape industry [12]. Initial work investigating optimal height of cut for older tall fescue cultivars, 
suggested that for optimal quality tall fescue should be mowed at a height ranging from 2.5 to $4 \mathrm{~cm}$ [13]. Moreover, lower mowing heights and higher mowing frequency were often associated with weed intrusion [13-15]. Natural sports field maintenance can be highly variable depending on geographical region, cultivar, and utilization. Newer dwarftype tall fescue cultivars are maintained in sports fields at a height ranging from 3.8 to $7.6 \mathrm{~cm}$ and fertilized with $1-2 \mathrm{~kg} \mathrm{~N}$ annually per $100 \mathrm{~m}^{2}$ [16,17]. More recently, Grossi et al. [5] assessed turfgrass quality of two improved turf type varieties (Arminda and Safari), mowed at four different heights $(10,15,20$, and $25 \mathrm{~mm}$ ) to evaluate their potential to constitute soccer pitches. The authors found that the highest turfgrass quality was observed when cultivars were mowed at $10 \mathrm{~mm}$, with traction not being affected by the mowing regime, and penetration resistance recorded within acceptable ranges for all the treatments, concluding that newer turf-type tall fescue cultivars could provide surface coverage suitable for soccer fields. McNitt et al., [18] found that traction increases in tall fescue when decreasing its cutting height, correlating this result with higher tiller density. Mixtures between tall fescue and Kentucky bluegrass have better quality when mowed at $20 \mathrm{~mm}$ than at $62 \mathrm{~mm}[19,20]$.

Combining tall fescue's stressor resistance, vigorous growth, and tolerance to lower mowing height of new dwarf-type cultivars grants the evaluation of performance of different cultivars when subjected to a low mowing regime. The objective of this study was to access the response of 20 cultivars of tall fescue when mowed continuously at $18 \mathrm{~cm}$ during a two-year period. The hypothesis of this study was that new and improved tall fescue cultivar can withstand frequent and low mowing heights.

\section{Materials and Methods}

A two-year study (from March 2018 to February 2020) was conducted on mature tall fescue turf at the Experimental Agricultural Farm of Padova University in Legnaro, northeastern Italy $\left(45^{\circ} 20^{\prime} \mathrm{N}, 11^{\circ} 57^{\prime} \mathrm{E} ; 8 \mathrm{~m}\right.$ asl $)$ on a coarse-silty, mixed, mesic, Oxyaquic Eutrudept [21] containing 30\% clay, $29 \%$ silt, and $41 \%$ sand, with a $\mathrm{pH}$ of $8.1,2.58 \%$ organic matter, a C/N ratio of 11.2, a total $\mathrm{N}$ content of $3.7 \mathrm{mg} \mathrm{g}^{-1}$ (combustion method), an Olsen $\mathrm{P}$ content of $5.3 \mathrm{mg} \mathrm{kg}^{-1}$, and an exchangeable K content of $108.3 \mathrm{mg} \mathrm{kg}^{-1}$ (buffered $\mathrm{BaCl} 2$ method). Annual minimum, average and maximum temperature are $8.0,12.6$, and $17.4{ }^{\circ} \mathrm{C}$ respectively, and annual average precipitation amount to $83142 \mathrm{~mm}_{\text {year }}{ }^{-1}$ (54 years data) [22]. Monthly precipitation and air temperatures during the investigation period are reported in Table 1.

Table 1. Monthly mean air temperatures and monthly precipitation during of the study period, and long-term averages (1964-2018) at the agricultural experimental farm of Padova University in Legnaro, northeastern Italy $\left(45^{\circ} 20^{\prime} \mathrm{N}, 11^{\circ} 57^{\prime} \mathrm{E}\right)$.

\begin{tabular}{|c|c|c|c|c|c|c|c|c|}
\hline \multirow[b]{2}{*}{ Month } & \multicolumn{4}{|c|}{ Air Temperature $\left({ }^{\circ} \mathrm{C}\right)$} & \multicolumn{4}{|c|}{ Precipitation $(\mathrm{mm})$} \\
\hline & 2018 & 2019 & 2020 & $54-y r$ avg & 2018 & 2019 & 2020 & 54-yr avg \\
\hline January & - & 2.2 & 3.3 & 2.2 & - & 9 & 14 & 52 \\
\hline February & - & 6.0 & 7.3 & 4.2 & - & 40 & 5 & 54 \\
\hline March & 7.1 & 9.8 & - & 8.1 & 139 & 10 & - & 62 \\
\hline April & 15.8 & 13.1 & - & 12.1 & 30 & 131 & - & 68 \\
\hline May & 19.7 & 14.8 & - & 17.0 & 70 & 201 & - & 77 \\
\hline June & 22.9 & 25.0 & - & 20.6 & 90 & 9 & - & 80 \\
\hline July & 24.6 & 24.5 & - & 22.8 & 101 & 82 & - & 74 \\
\hline August & 25.2 & 24.5 & - & 22.3 & 109 & 16 & - & 72 \\
\hline September & 20.7 & 19.6 & - & 18.3 & 16 & 68 & - & 74 \\
\hline October & 15.6 & 15.7 & - & 13.2 & 142 & 61 & - & 80 \\
\hline November & 10.2 & 10.6 & - & 7.4 & 63 & 150 & - & 82 \\
\hline December & 3.0 & 5.7 & - & 2.9 & 12 & 90 & - & 58 \\
\hline Year & 14.5 & 14.3 & 14.9 & 12.6 & 853 & 867 & 596 & 820 \\
\hline
\end{tabular}


Twenty tall fescue cultivars ('Ares', 'Armani', 'Dynamites LS', 'Firecracker SLS', 'Firewall', 'Foxhound' 'Granditte', 'JT-LT2', 'JT-338', 'Karakum', 'Lexington', 'Olympic Gold', 'Rebounder', 'Rhambler SRP', 'Starlett', 'Supersonic', 'Talladega', 'Thunderstruck', 'Titanium 2LS', 'Turfway'-Table S1) were seeded on September 2017 at $40 \mathrm{~g} \mathrm{~m}^{-2}$. From the establishment, turf was fertilized at $200 \mathrm{~kg} \mathrm{ha}^{-1}$ year $^{-1}$ with a controlled released fertilizer (24-5-8), in two fertilization events (March and September). Turf was irrigated with potable water from a nearby aquifer ( $\mathrm{pH} 7.7$, TDS $328 \mathrm{mg} \mathrm{L}^{-1}$ ) from mid-June to mid-August of every year at $80 \%$ reference evapotranspiration $\left(\mathrm{ET}_{\mathrm{o}}\right)$ with weekly irrigation events to prevent drought stress using a sprinkling irrigation system. From March 12018 plots were mowed weekly at $18 \mathrm{~mm}$ using a reel mower (seven-blade reel; McLane, Bell Gradens, CA, USA). Grass weeds were manually removed, while broadleaf weeds were controlled using Vithal Turfene plus selective herbicide (Dicamba/MCPP-P-500 $1 \mathrm{ha}^{-1}$ of $10 \mathrm{~mL}^{-1}$ solution) with an electric knapsack sprayer (Ergo 12, Stocker, Bolzano, Italy). Disease control strategy did not include pesticide applications.

From March 1 2018, plots were evaluated every two weeks for turfgrass visual quality, color, density, texture and uniformity on a scale from 1 to $9(1=$ worst; $9=$ best; $6=$ minimal acceptable level) [23], as well as percent green cover (PGC) and dark green color index (DGCI) through digital image analysis (DIA) using a Canon Powershot G12 (shutter speed $1 / 400 \mathrm{~s}$, aperture F4.0, focal length $32 \mathrm{~mm}$, hue range from 57 to 107 saturation range from 0 to 100) [24], and normalized difference vegetation index (NDVI; GreenSeeker Handheld Crop Sensor, Trimble Navigation Unlimited, Sunnyvale, CA, USA). Moreover, traction required to calculate the amount of power required to break or tear a turfgrass stand was assessed twice a year (during spring and fall, when soccer game pressure is the highest in Northern Italy) using a traction plate (TSHEAR2-M, Turf-Tech, Tallahassee, FL, USA) with four readings per plot [25]. According to McAuliffe [26], optimal ranges for soccer field in the Australian Football League are 4 to $5.5 \mathrm{~kg} \mathrm{~m}^{-1}$ for ideal traction strength, with unacceptably low strength below $2 \mathrm{~kg} \mathrm{~m}^{-1}$.

The experimental design was a completely randomized block design with three replications, and plot size of $4 \mathrm{~m}^{2}(2 \mathrm{~m} \times 2 \mathrm{~m})$. Biweekly ratings were averaged over month to allow comparison between the two years. Data were subjected to analysis of variance (ANOVA) with a repeated measure analysis using a compound symmetry covariance structure (Statistical Analysis Software, SAS Proc Mixed version 9.4; SAS Institute, Cary, NC, USA). Normality and homoscedasticity of residuals were checked by using graphical analyses. When appropriate, means were separated with Fisher's protected least significant difference at 0.05 probability level.

\section{Results}

All the ratings with the exception of NDVI were affected by the interaction of month and cultivar (Table 2) and all ratings were affected by the interaction between month and year (data not shown). Based on the aim of the study that would evaluate the performance of the cultivars, only parameters with significant interactions involving cultivars are treated in this section.

Table 2. Results of analysis of variance testing the effects of year, month, and cultivar and their interactions on turf quality, color, density, texture and uniformity percent green cover (PGC), dark green color index (DGCI), and normalized difference vegetation index (NDVI) of tall fescue.

\begin{tabular}{|c|c|c|c|c|c|c|c|c|}
\hline & Quality & Color & Density & Texture & Uniformity & PGC & DGCI & NDVI \\
\hline Cultivar (C) & $* * *$ & $* * *$ & $* * *$ & $* * *$ & $* * *$ & $* * *$ & $* * *$ & $\mathrm{NS}^{+}$ \\
\hline Year $(\mathrm{Y})$ & $* * *$ & $* * *$ & NS & $* * *$ & $* * *$ & $* * *$ & NS & $* *$ \\
\hline $\mathrm{Y}^{*} \mathrm{C}$ & $* * *$ & $* * *$ & NS & NS & $* * *$ & $* * *$ & NS & NS \\
\hline Month (M) & $* * *$ & $* * *$ & $* * *$ & $* * *$ & $* * *$ & $* * *$ & $* * *$ & $* * *$ \\
\hline $\mathrm{M}^{*} \mathrm{C}$ & $* * *$ & $* * *$ & $* * *$ & $* * *$ & $* * *$ & $* * *$ & $* * *$ & NS \\
\hline $\mathrm{Y}^{*} \mathrm{M}$ & $* * *$ & $* * *$ & $* * *$ & $* * *$ & $* * *$ & $* * *$ & $* * *$ & $* * *$ \\
\hline $\mathrm{Y}^{*} \mathrm{M}^{*} \mathrm{C}$ & NS & NS & NS & NS & NS & NS & NS & NS \\
\hline
\end{tabular}

${ }^{*}$ Significant $\mathrm{F}$ test at the 0.05 level of probability. ${ }^{* *}$ Significant $\mathrm{F}$ test at the 0.01 level of probability. ${ }^{* * *}$ Significant $\mathrm{F}$ test at the 0.001 level of probability. $\mathrm{NS}^{\dagger}{ }^{\dagger}$, nonsignificant at the 0.05 probability level. 
All cultivars had higher turfgrass quality between April and June, or in October and November (Table 3); conversely, the only two months when all cultivars did not achieve acceptable quality were February and March. Among cultivars, 'Turfway' showed the best quality during the spring months, while 'Titanium 2LS' and 'JT-338' followed by 'Turfway' achieved best quality in October and November. Several cultivars dropped below acceptable quality levels also in August (Table 4). 'Titanium 2LS' and 'JT-338' were also the only cultivar with higher turfgrass quality during year 1 compared to year 2 (Figure 1). Conversely, 'Ares', and 'JT-LT2' decreased their quality during year 2 (Figure 1).

Table 3. Turfgrass visual quality of 20 tall fescue cultivars mowed weekly at $18 \mathrm{~mm}$ in Legnaro, PD (Italy). Data are pooled over two years and three replicates.

\begin{tabular}{|c|c|c|c|c|c|c|c|c|c|c|c|c|}
\hline & Jan & Feb & Mar & Apr & May & Jun & Jul & Aug & Sep & Oct & Nov & Dec \\
\hline Ares & 6.7 & 5.0 & 5.5 & 6.9 & 7.3 & 7.5 & 6.5 & 5.5 & 5.8 & 6.7 & 7.1 & 7.4 \\
\hline Armani & 5.0 & 4.7 & 5.1 & 5.1 & 5.5 & 5.8 & 5.6 & 5.1 & 5.8 & 6.6 & 6.4 & 6.5 \\
\hline Dynamites LS & 6.4 & 5.3 & 5.4 & 6.9 & 7.1 & 7.3 & 6.6 & 5.2 & 5.9 & 7.1 & 7.5 & 7.3 \\
\hline Firecracker SLS & 6.2 & 5.0 & 5.4 & 6.6 & 6.8 & 7.0 & 6.6 & 5.9 & 6.3 & 7.3 & 7.4 & 7.3 \\
\hline Firewall & 5.8 & 5.0 & 5.2 & 6.3 & 6.5 & 6.9 & 6.7 & 6.2 & 6.6 & 7.6 & 7.6 & 7.2 \\
\hline Foxhound & 6.7 & 4.7 & 5.4 & 7.4 & 7.7 & 7.6 & 7.1 & 6.1 & 6.6 & 7.5 & 7.6 & 7.5 \\
\hline Granditte & 6.1 & 5.0 & 5.3 & 6.4 & 6.7 & 6.9 & 6.9 & 6.7 & 6.9 & 7.8 & 7.9 & 7.2 \\
\hline JT-338 & 6.3 & 4.2 & 4.9 & 7.4 & 7.7 & 7.8 & 7.5 & 6.2 & 7.1 & 8.1 & 8.2 & 7.7 \\
\hline JT-LT2 & 6.4 & 5.0 & 5.2 & 7.0 & 7.0 & 6.8 & 5.6 & 5.3 & 6.0 & 6.7 & 6.9 & 7.3 \\
\hline Karakum & 5.4 & 4.7 & 5.0 & 5.8 & 6.3 & 6.5 & 6.3 & 5.5 & 6.3 & 6.7 & 6.8 & 6.3 \\
\hline Lexington & 5.4 & 4.7 & 5.4 & 6.1 & 6.3 & 6.3 & 6.1 & 5.6 & 6.2 & 6.8 & 6.9 & 6.5 \\
\hline Olympic Gold & 5.1 & 4.0 & 4.7 & 5.7 & 5.7 & 5.8 & 5.3 & 4.7 & 5.2 & 6.0 & 6.1 & 6.1 \\
\hline Rebounder & 6.5 & 4.8 & 5.6 & 7.2 & 7.4 & 7.4 & 7.0 & 5.9 & 6.6 & 7.6 & 7.8 & 7.4 \\
\hline Rhambler srp & 6.0 & 4.3 & 5.3 & 6.5 & 6.6 & 6.9 & 6.8 & 6.1 & 6.8 & 7.6 & 7.7 & 7.2 \\
\hline Starlett & 5.1 & 4.5 & 4.9 & 5.6 & 5.8 & 6.0 & 5.4 & 4.8 & 5.6 & 6.3 & 6.2 & 6.2 \\
\hline Supersonic & 6.1 & 4.5 & 5.3 & 6.4 & 6.6 & 6.8 & 6.6 & 6.1 & 6.2 & 7.2 & 7.5 & 7.0 \\
\hline Talladega & 5.3 & 4.5 & 4.7 & 6.1 & 6.4 & 6.6 & 6.1 & 5.5 & 5.9 & 6.7 & 6.8 & 6.4 \\
\hline Titanium 2LS & 5.9 & 4.7 & 5.3 & 7.3 & 7.3 & 7.3 & 6.7 & 5.6 & 6.2 & 7.0 & 7.2 & 7.4 \\
\hline Thunderstruck & 6.1 & 4.7 & 5.0 & 7.0 & 7.3 & 7.6 & 6.8 & 6.4 & 6.9 & 8.0 & 8.1 & 7.3 \\
\hline $\begin{array}{c}\text { Turfway } \\
\text { LSD }^{+}=0.2\end{array}$ & 7.0 & 5.3 & 5.8 & 7.8 & 8.1 & 8.1 & 7.3 & 6.1 & 6.9 & 7.8 & 7.9 & 7.7 \\
\hline
\end{tabular}

${ }^{\dagger}$ To determine statistical differences among entries, subtract one entry's mean from another entry's mean. Statistical differences occur when this value is larger than the corresponding LSD value $(p<0.05)$.

Table 4. Percent green cover (\%) of 20 tall fescue cultivars mowed weekly at $18 \mathrm{~mm}$ in Legnaro, PD (Italy). Data are pooled over two years and three replicates.

\begin{tabular}{|c|c|c|c|c|c|c|c|c|c|c|c|c|}
\hline & Jan & Feb & Mar & Apr & May & Jun & Jul & Aug & Sep & Oct & Nov & Dec \\
\hline Ares & 74 & 64 & 84 & 93 & 93 & 94 & 88 & 84 & 88 & 92 & 91 & 90 \\
\hline Armani & 80 & 73 & 86 & 89 & 92 & 96 & 93 & 89 & 93 & 94 & 92 & 91 \\
\hline Dynamites LS & 73 & 66 & 84 & 93 & 93 & 95 & 91 & 87 & 90 & 92 & 92 & 89 \\
\hline Firecracker SLS & 80 & 71 & 85 & 93 & 94 & 96 & 92 & 90 & 93 & 93 & 93 & 92 \\
\hline Firewall & 79 & 70 & 84 & 92 & 94 & 96 & 90 & 90 & 93 & 95 & 94 & 91 \\
\hline Foxhound & 71 & 60 & 81 & 94 & 94 & 94 & 90 & 87 & 90 & 93 & 91 & 87 \\
\hline Granditte & 78 & 72 & 83 & 91 & 94 & 96 & 92 & 91 & 94 & 94 & 93 & 91 \\
\hline JT-338 & 75 & 64 & 81 & 94 & 95 & 96 & 93 & 90 & 92 & 94 & 92 & 89 \\
\hline JT-LT2 & 68 & 56 & 82 & 94 & 94 & 95 & 91 & 87 & 89 & 88 & 89 & 87 \\
\hline Karakum & 75 & 67 & 84 & 93 & 95 & 96 & 94 & 89 & 93 & 94 & 91 & 89 \\
\hline Lexington & 74 & 67 & 85 & 91 & 93 & 95 & 93 & 88 & 91 & 92 & 91 & 89 \\
\hline Olympic Gold & 70 & 65 & 84 & 93 & 92 & 94 & 89 & 85 & 90 & 91 & 89 & 87 \\
\hline Rebounder & 76 & 67 & 85 & 94 & 94 & 95 & 90 & 88 & 91 & 94 & 92 & 91 \\
\hline Rhambler srp & 76 & 69 & 85 & 94 & 95 & 96 & 93 & 89 & 93 & 94 & 92 & 90 \\
\hline Starlett & 70 & 64 & 84 & 90 & 92 & 94 & 89 & 80 & 88 & 92 & 91 & 84 \\
\hline Supersonic & 78 & 72 & 85 & 92 & 94 & 96 & 92 & 90 & 92 & 93 & 91 & 92 \\
\hline Talladega & 76 & 67 & 84 & 94 & 94 & 95 & 91 & 86 & 91 & 93 & 91 & 89 \\
\hline
\end{tabular}


Table 4. Cont.

\begin{tabular}{ccccccccccccc}
\hline & Jan & Feb & Mar & Apr & May & Jun & Jul & Aug & Sep & Oct & Nov & Dec \\
\hline Thunderstruck & 74 & 65 & 82 & 91 & 92 & 93 & 89 & 81 & 88 & 91 & 89 & 86 \\
Titanium 2LS & 81 & 73 & 83 & 94 & 95 & 96 & 92 & 91 & 94 & 95 & 94 & 93 \\
Turfway & 72 & 65 & 85 & 94 & 94 & 95 & 91 & 87 & 90 & 93 & 91 & 90
\end{tabular}

$$
\operatorname{LSD}^{+}=2
$$

${ }^{\dagger}$ To determine statistical differences among entries, subtract one entry's mean from another entry's mean. Statistical differences occur when this value is larger than the corresponding LSD value $(p<0.05)$.
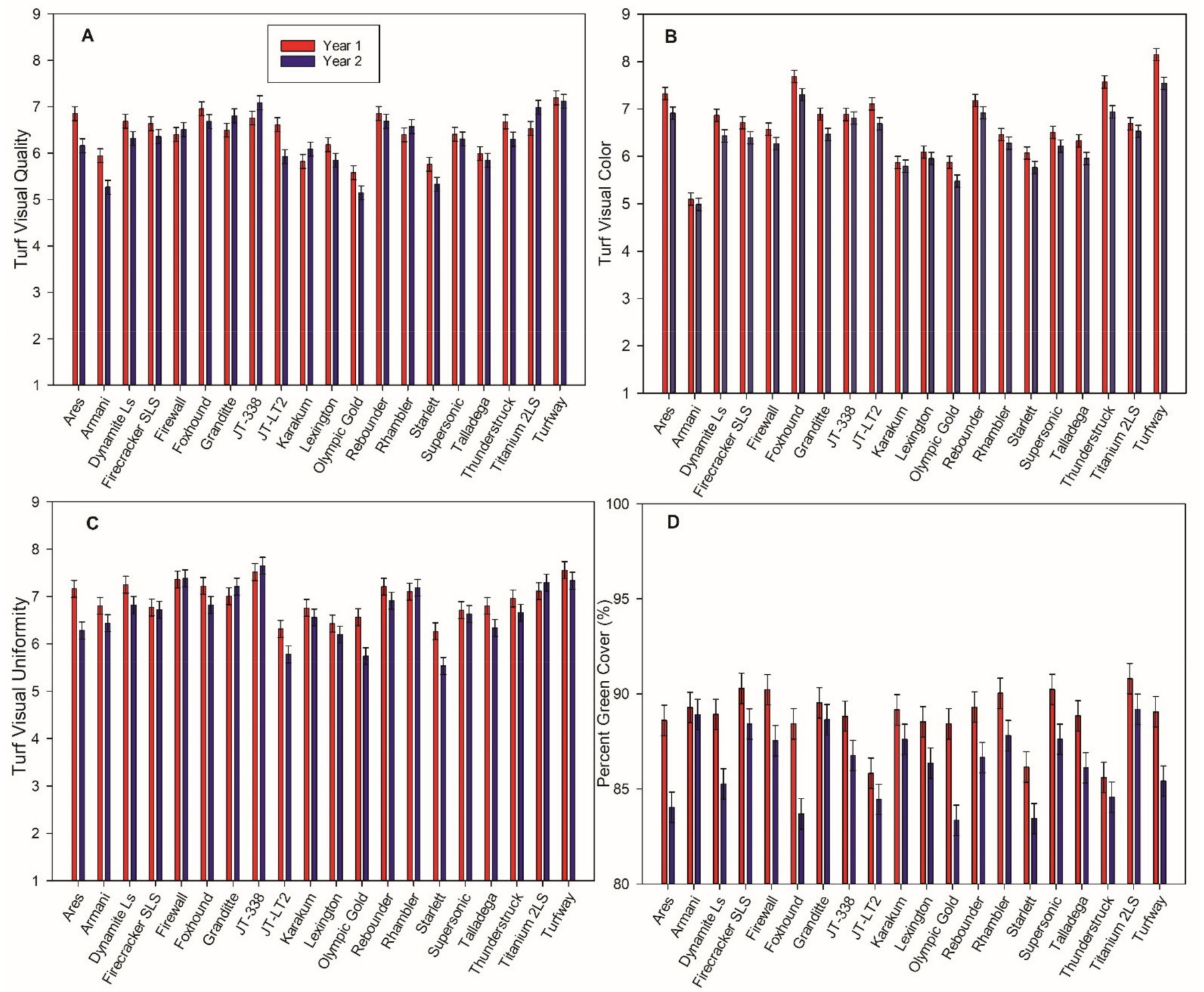

Figure 1. Turf visual quality (A), color (B), uniformity (C) on a scale from 1 to $9(1=$ worst, $9=$ best, $6=$ minimum acceptable quality), and percent green cover (\%) (D) of 20 tall fescue cultivars mowed weekly at $18 \mathrm{~mm}$ in Legnaro, PD (Italy). Data are pooled over 12 months and three replicates.

Trends for turf visual color resembled those of visual quality, with insufficient color ratings recorded in all the cultivar in February (Table S2). 'Turfway' together with 'Thunderstruck' and 'Foxhound' were the cultivars with the highest visual color. Moreover, 'Turfway' maintained higher turf color compared to the other cultivars also during the winter (Table S2). However, the three cultivars showed darker green color during year 1 compared to year 2 (Figure 1). When averaged over month, only 'Armani' and 'Karakum' 
did not show acceptable color ratings (Figure 1). All cultivars maintained sufficient visual density throughout the year (Table S3). Similar to visual quality, the highest density was recorded in 'Titanium 2LS' and 'JT-338' in October and November (Table S3). Conversely, being a genetic characteristic, less differences among months were detected for visual texture. 'Olympic gold' was the only cultivar that never showed sufficient leaf texture (Table S4). Similarly, 'Starlett' showed acceptable texture only in July, and 'Telladega' in June and December. 'JT-338' and 'Armani' were the cultivars with the best (finer) texture (Table S4). Visual uniformity generally decreased during summer, with only 14 cultivars having sufficient uniformity in August (Table S5). Conversely, highest uniformity was recorded during spring and autumn. Highest uniformity was achieved by 'JT-338' in May, June, October and November. Uniformity of the cultivars was comparable across both years for most of the tested cultivars, however 'Ares', 'JT-LT2', 'Olympic Gold', and 'Starlett' showed differences between the two years (Figure 1).

Percent green cover of all cultivars dropped during the winter months (Table 4). In January and February 'Titanium 2LS' was the cultivar with the highest PGC. From May until December, all cultivars had PGC higher than $80 \%$, and the majority of them had PGC higher than $90 \%$ from April to November, with no differences among cultivars detected from April until June (Table 4).

'Armani', 'Granditte', and 'Thunderstruck' were the only cultivars with comparable PGC from year 1 to year 2 (Figure 1). Highest DGCIs were collected in November for every cultivar (Table 5), with 'Ares' 'Dynamite 1s', 'Thunderstruck', and 'Turfway' achieving the highest DGCI among cultivars. Dark green color index was often comparable among cultivars. However, through the year, 'Armani' had lower DGCI than the rest of the cultivars.

Table 5. Dark green color index (DGCI) of 20 tall fescue cultivars mowed weekly at $18 \mathrm{~mm}$ in Legnaro, PD (Italy). Data are pooled over two years and three replicates.

\begin{tabular}{|c|c|c|c|c|c|c|c|c|c|c|c|c|}
\hline & Jan & Feb & Mar & Apr & May & Jun & Jul & Aug & Sep & Oct & Nov & Dec \\
\hline Ares & 0.61 & 0.65 & 0.66 & 0.64 & 0.63 & 0.64 & 0.60 & 0.59 & 0.63 & 0.67 & 0.70 & 0.64 \\
\hline Armani & 0.51 & 0.52 & 0.54 & 0.55 & 0.55 & 0.58 & 0.54 & 0.55 & 0.57 & 0.59 & 0.59 & 0.57 \\
\hline Dynamites LS & 0.64 & 0.63 & 0.64 & 0.63 & 0.62 & 0.64 & 0.59 & 0.59 & 0.63 & 0.67 & 0.70 & 0.65 \\
\hline Firecracker SLS & 0.58 & 0.57 & 0.61 & 0.62 & 0.61 & 0.64 & 0.60 & 0.58 & 0.63 & 0.66 & 0.67 & 0.62 \\
\hline Firewall & 0.57 & 0.55 & 0.61 & 0.62 & 0.61 & 0.63 & 0.58 & 0.58 & 0.62 & 0.65 & 0.67 & 0.64 \\
\hline Foxhound & 0.59 & 0.63 & 0.66 & 0.66 & 0.64 & 0.65 & 0.61 & 0.59 & 0.64 & 0.68 & 0.69 & 0.66 \\
\hline Granditte & 0.59 & 0.57 & 0.63 & 0.62 & 0.62 & 0.65 & 0.61 & 0.58 & 0.63 & 0.66 & 0.66 & 0.63 \\
\hline JT-338 & 0.60 & 0.63 & 0.65 & 0.65 & 0.63 & 0.64 & 0.61 & 0.58 & 0.63 & 0.67 & 0.68 & 0.65 \\
\hline JT-LT2 & 0.67 & 0.67 & 0.67 & 0.64 & 0.61 & 0.63 & 0.58 & 0.59 & 0.62 & 0.66 & 0.69 & 0.65 \\
\hline Karakum & 0.54 & 0.56 & 0.60 & 0.60 & 0.60 & 0.63 & 0.59 & 0.57 & 0.61 & 0.64 & 0.64 & 0.60 \\
\hline Lexington & 0.55 & 0.57 & 0.60 & 0.60 & 0.60 & 0.62 & 0.59 & 0.57 & 0.61 & 0.64 & 0.64 & 0.59 \\
\hline Olympic Gold & 0.53 & 0.56 & 0.60 & 0.59 & 0.59 & 0.61 & 0.58 & 0.57 & 0.60 & 0.62 & 0.65 & 0.60 \\
\hline Rebounder & 0.61 & 0.62 & 0.65 & 0.64 & 0.62 & 0.64 & 0.59 & 0.58 & 0.62 & 0.67 & 0.68 & 0.64 \\
\hline Rhambler srp & 0.56 & 0.57 & 0.62 & 0.63 & 0.61 & 0.64 & 0.59 & 0.57 & 0.62 & 0.65 & 0.65 & 0.62 \\
\hline Starlett & 0.54 & 0.54 & 0.60 & 0.59 & 0.58 & 0.60 & 0.58 & 0.56 & 0.61 & 0.64 & 0.65 & 0.59 \\
\hline Supersonic & 0.57 & 0.57 & 0.63 & 0.62 & 0.62 & 0.64 & 0.60 & 0.58 & 0.62 & 0.66 & 0.67 & 0.64 \\
\hline Talladega & 0.57 & 0.58 & 0.61 & 0.62 & 0.60 & 0.63 & 0.59 & 0.57 & 0.61 & 0.64 & 0.65 & 0.60 \\
\hline Thunderstruck & 0.62 & 0.63 & 0.65 & 0.64 & 0.62 & 0.64 & 0.60 & 0.62 & 0.65 & 0.67 & 0.70 & 0.69 \\
\hline Titanium 2LS & 0.59 & 0.56 & 0.61 & 0.64 & 0.62 & 0.63 & 0.59 & 0.58 & 0.63 & 0.67 & 0.67 & 0.65 \\
\hline $\begin{array}{c}\text { Turfway } \\
\text { LSD }^{+}=0.02\end{array}$ & 0.63 & 0.63 & 0.65 & 0.65 & 0.64 & 0.65 & 0.62 & 0.58 & 0.63 & 0.68 & 0.70 & 0.67 \\
\hline
\end{tabular}

${ }^{\dagger}$ To determine statistical differences among entries, subtract one entry's mean from another entry's mean. Statistical differences occur when this value is larger than the corresponding LSD value $(p<0.05)$.

Traction was influenced by the interaction of year and season $(p<0.05$; data not shown). Lowest traction was recorded in the spring of $2018\left(2.4 \mathrm{~kg} \mathrm{~m}^{-1}\right)$. Fall of 2018 and 2019 were comparable within each other $\left(2.8 \mathrm{~kg} \mathrm{~m}^{-1}\right)$, while highest traction was required 
to tear the turf shield during the spring of 2019 (3.5 $\mathrm{kg} \mathrm{m}^{-1}$; data not shown). Similar to NDVI, cultivar never influenced traction strength (data not shown).

\section{Discussion}

In Northern Italy, athletic fields are used predominantly during the cooler months, when the majority of soccer and rugby games are played [3]. For this reason, cool-season turfgrasses are still the preferred species by sports managers. Tall fescue is the most widely used turf species in Italy and in the Mediterranean Europe [27,28], however, despite its tolerance to wear that makes it a suitable species for trafficked areas [29], its use is still limited mostly to landscape areas. Identifying cultivars that can withstand low mowing will help sports turf managers accepting tall fescue as a possible alternative for the constitution of sports fields. Although no cultivars could sustain sufficient quality ratings through the year (Table 3), and in general visual ratings and PGC dropped during the winter months (Table 4), significant differences were detected among cultivars in this study. Cultivars like 'Turfway', 'Titanium 2LS' and 'JT-338' achieved high quality rating during spring and fall, the two seasons with the highest frequency of games played on sports field in northern Italy. 'Titanium 2LS' and 'JT-338' also had the highest density overall, which is a crucial factor for sport fields. Moreover, turf quality for 'Titanium 2LS' and 'JT-338' was higher during the second year of the trial, suggesting that low mowing could be tolerated for multiple years. 'JT-338' also displayed high rates of texture compared to others cultivars. Finer leaf texture would also increase tall fescue appeal among sport managers [3,30]; in this study the cultivars with the finer texture was 'Armani' (Table S4); however, its fine texture did not translate to sufficient turfgrass quality from winter to summer (Table 3); moreover 'Armani' turfgrass quality decreased from the first to the second year of the trial, and its color ratings and DGCIs were among the lowest (Tables S2 and S5). Insufficient quality ratings for tall fescue during the winter months have previously been documented in Northern Italy [4]. However, intensifying management practices, e.g., use of plant growth regulator, biostimulants, and increasing $\mathrm{N}$ rates during the winter months could help managers sustain turfgrass quality in January and February $[4,31]$.

Cultivar selection did not influence traction. According to McAuliffe [26], traction measurements in this study fell in the 'low normal' category for Australian Football League recommendations. However, warm-season species that are currently used in Australia in athletic fields, have higher traction values than cool-season species [32]. Values recorded in this study are in range with those collected on kikuygrass [Cenchrus clandestinus (Hochst. ex Chiov.) Morrone] in a Mediterranean climate [33]. Moreover, the lowest value was recorded only six months after turfgrass establishment, and increased ever since. Therefore, tension values recorded in this trial should not represent a concern for turfgrass managers.

\section{Conclusions}

Thanks to its adaptation to the Northern Italian climate, and its resistance to abiotic stressors compared to other cool-season species, tall fescue is the most widely used turfgrass species in the European transition zone. Identifying cultivars that can withstand low mowing heights could help sport fields managers' acceptance of tall fescue. This study revealed that, when mowed at $18 \mathrm{~mm}$ several differences exist among new tall fescue cultivars, and not many cultivars can be used in sport fields. Breeding efforts could focus on cultivars with thinner leaf texture that could withstand frequent low mowing heights. However, 'Turfway', 'Titanium 2LS' and 'JT-338' showed promising results, with quality ratings dropping below acceptable levels only during the winter months. Moreover, traction measurements do not raise a concern for turfgrass managers.

Supplementary Materials: The following are available online at https: / www.mdpi.com/article / 10.3390/agronomy11050943/s1, Table S1: Tall fescue cultivars and their associated distribution company tested at the agricultural experimental farm of Padova University in Legnaro, northeastern Italy $\left(45^{\circ} 20^{\prime} \mathrm{N}, 11^{\circ} 57^{\prime} \mathrm{E}\right)$; Table S2: Turfgrass visual color of 20 tall fescue cultivars mowed weekly at $18 \mathrm{~mm}$ in Legnaro, PD (Italy). Data are pooled over 2 years and 3 replicates; Table S3: Turfgrass visual 
density of 20 tall fescue cultivars mowed weekly at $18 \mathrm{~mm}$ in Legnaro, PD (Italy). Data are pooled over 2 years and 3 replicates; Table S4: Turfgrass visual texture of 20 tall fescue cultivars mowed weekly at $18 \mathrm{~mm}$ in Legnaro, PD (Italy). Data are pooled over 2 years and 3 replicates; Table S5: Turfgrass visual uniformity of 20 tall fescue cultivars mowed weekly at $18 \mathrm{~mm}$ in Legnaro, PD (Italy). Data are pooled over 2 years and 3 replicates.

Author Contributions: Conceptualization, S.M.; methodology, S.M.; software, M.S.; validation, S.M. and M.S.; formal analysis, M.S.; investigation, C.P.; resources, S.M.; data curation, M.S.; writingoriginal draft preparation, M.S.; writing-review and editing, C.P. and M.S.; visualization, M.S.; supervision, S.M.; project administration, S.M.; funding acquisition, S.M. All authors have read and agreed to the published version of the manuscript.

Funding: This research was funded by Padana Sementi Elette s.r.l.

Institutional Review Board Statement: Not applicable.

Informed Consent Statement: Not applicable.

Acknowledgments: The Authors thank the staff of the Experimental Agricultural Farm of the University of Padova for the efficient work in managing field plots, and Filippo Lazzaretto for help in the field activity.

Conflicts of Interest: The authors declare no conflict of interest.

\section{References}

1. Schiavon, M.; Leinauer, B.; Serena, M.; Sallenave, R.; Maier, B. Establishing tall fescue and Kentucky bluegrass using subsurface irrigation and saline water. Agron. J. 2013, 105, 183-190.

2. Schiavon, M.; Green, R.L.; Baird, J.H. Drought tolerance of cool-season turfgrasses in a Mediterranean climate. Eur. J. Hortic. Sci. 2014, 79, 175-182.

3. Pornaro, C.; Barolo, E.; Rimi, F.; Macolino, S.; Richardson, M. Performance of various cool-season turfgrasses as influenced by simulated traffic in northeastern Italy. Eur. J. Hortic. Sci. 2016, 81, 27-36.

4. Schiavon, M.; Pornaro, C.; Macolino, S. Tall Fescue (Schedonorus arundinaceus (Schreb.) Dumort.) Turfgrass Cultivars Performance under Reduced N Fertilization. Agronomy 2021, 11, 193. [CrossRef]

5. Grossi, N.; Volterrani, M.; Magni, S.; Miele, S. Tall fescue turf quality and soccer playing characteristics as affected by mowing height. Int. Turfgrass Soc. Res. J. 2003, 661, 319-322.

6. Stier, J.C.; Koeritz, E.J. Seeding dates for tall fescue (Festuca arundinacea Schreb.) athletic fields established in a temperate continental climate. Acta Hortic. 2008, 783, 19-27.

7. Jernstedt, J.A.; Bouton, J.H. Anatomy, morphology, and growth of tall fescue rhizomes. Crop Sci. 1985, 25, 539-542.

8. Beard, J.B. Turfgrass: Science and Culture; Prentice-Hall: Englewood Cliffs, NJ, USA, 1973.

9. Hall, J.R., III. Effect of cultural factors on tall fescue- Kentucky bluegrass sod quality and botanical composition. Int. Turfgrass Soc. Res. J. 1980, 4, 367-377.

10. Hall, J.R., III; Taylor, L.H. Impact of companion crop and fertilization on tall fescue sod production. Int. Turfgrass Soc. Res. J. 1989, 6, 259-261.

11. Dunn, J.H.; Ervin, E.H.; Fresenburg, B.S. Turf performance of mixtures and blends of tall fescue, Kentucky bluegrass, and perennial ryegrass. HortScience 2002, 37, 214-217.

12. Carrow, R.N. Drought avoidance characteristics of diverse tall fescue cultivars. Crop Sci. 1996, 36, 371-377.

13. Burns, R.E. Time of fertilizer application as it affects quality of tall fescue turf. In Proceedings of the 4th International Turfgrass Research Conference, Guelph, ON, Canada, 19-23 July 1981; Sheard, R.W., Ed.; University of Guelph: Guelph, ON, Canada, 1981; pp. 285-291.

14. Dernoeden, P.H.; Carroll, M.J.; Krouse, J.M. Weed management and tall fescue quality as influenced by mowing, nitrogen, and herbicides. Crop Sci. 1993, 33, 1055-1061.

15. Pirchio, M.; Fontanelli, M.; Frasconi, C.; Martelloni, L.; Raffaelli, M.; Peruzzi, A.; Gaetani, M.; Magni, S.; Caturegli, L.; Volterrani, M.; et al. Autonomous Mower vs. Rotary Mower: Effects on Turf Quality and Weed Control in Tall Fescue Lawn. Agronomy 2018, 8, 15 .

16. Puhalla, J.; Krans, J.; Goatley, M. Sports Fields: A Manual for Design, Construction and Maintenance; John Wiley \& Sons Inc.: Hoboken, NJ, USA, 2010.

17. Straw, C.M.; Samson, C.O.; Henry, G.M.; Brown, C.N. A review of turfgrass sports field variability and its implications on athlete-surface interactions. Agron. J. 2020, 112, 2401-2417. [CrossRef]

18. McNitt, A.S.; Landschoot, P.J.; Waddington, D.V. Effects of turfgrass, cutting height and soil conditions on traction. In Proceedings of the I International Conference on Turfgrass Management and Science for Sports Fields, Acta Horticulturae 661. Athens, Greece, 2-7 June 2003; International Society for Horticultural Science: Leuven, Belgium, 2004. Volume 1. pp. 39-48. 
19. Macolino, S.; Pignata, G.; Giolo, M.; Richardson, M.D. Species succession and turf quality of tall fescue and Kentucky bluegrass mixtures as affected by mowing height. Crop Sci. 2014, 54, 1220-1226.

20. Pornaro, C.; Masin, R.; Macolino, S.; Richardson, M.D. Botanical composition of tall fescue-Kentucky bluegrass turfgrass mixtures is sustained in long-term study. Eur. J. Hortic. Sci.. in press.

21. Morari, F. Drainage flux measurement and errors associated with automatic tension-controlled suction plates. Soil Sci. Soc. Am. J. 2006, 70, 1860-1871.

22. Regional Agency for Environmental Protection of Veneto Region (ARPAV). Dipartimento Per La Sicurezza Del Territorio. Centro Meterologico: Teolo, Padova, Italy. Available online: http://www.arpa.veneto.it/dati-ambientali/open-data/clima/principalivariabili-meteorologiche (accessed on 23 October 2020).

23. Krans, J.V.; Morris, K. Determining a profile of protocols and standards used in the visual field assessment of turfgrasses: A survey of national turfgrass evaluation program-sponsored university scientists. Appl. Turfgrass Sci. 2007, 4, 1-6.

24. Karcher, D.E.; Richardson, M.D. Quantifying turfgrass color using digital image analysis. Crop Sci. 2003, 43, 943-951.

25. Canaway, P.M.; Bell, M.J. An apparatus for measuring traction and friction on natural and artificial playing surfaces. J. Sports Turf Res. Inst. 1986, 62, 211-214.

26. McAuliffe, K.W. The role of performance testing and standards in the sports turf industry: A case study approach. Acta Hortic. 2008, 783, 391-398. [CrossRef]

27. Volterrani, M.; Magni, S. Species and growing media for sports turfs in Mediterranean area. Acta Hortic. 2004, 661, 359-364.

28. Schiavon, M.; Barnes, B.D.; Shaw, D.A.; Henry, J.M.; Baird, J.H. Strategies for converting tall fescue to warm-season turf in a Mediterranean climate. HortTechnology 2013, 23, 442-448. [CrossRef]

29. Park, B.S.; Lawson, T.J.; Samaranayake, H.; Murphy, J.A. Tolerance and recovery of Kentucky bluegrass subjected to seasonal wear. Crop Sci. 2010, 50, 1526-1536. [CrossRef]

30. Miele, S.; Volterrani, M.; Magni, S.; Gaetani, K. Winter quality of tall fescue turf: Effects of renovation technique and nitrogen fertilization. Italian J. Agron. 2002, 6, 97-101.

31. Tucker, B.J.; McCarty, L.B.; Liu, H.; Wells, C.E.; Rieck, J.R. Mowing Height, Nitrogen Rate, and Biostimulant Influence Root Development of Field-grownTifEagle'Bermudagrass. HortScience 2006, 41, 805-807.

32. Thomson, A.; Whiteley, R.; Wilson, M.; Bleakley, C. Six different football shoes, one playing surface and the weather; Assessing variation in shoe-surface traction over one season of elite football. PLOS ONE 2019, 14, e0216364.

33. Schiavon, M.; Mock, T.; Stowell, L.J.; Baird, J. Management practices for optimal kikuyugrass quality and playing conditions. Agron. J. 2020, 112, 3402-3410. [CrossRef] 